PDFlib PLOP: PDF Linearization, Optimization, Protection

Page inserted by evaluation version www.pdflib.com - sales@pdflib.com 


\title{
Mechanisms Involved in Calcium-Dependent Exocytosis ${ }^{a}$
}

\author{
RONALD W. HOLZ, JAN SENYSHYN, \\ AND MARY A. BITTNER \\ Department of Pharmacology \\ M6322 Medical Science I \\ University of Michigan Medical School \\ Ann Arbor, Michigan 48109-0626
}

\begin{abstract}
Although a great deal is known concerning the membrane events controlling $\mathrm{Ca}^{2+}$ influx and metabolism, the events triggered by $\mathrm{Ca}^{2+}$ that lead to exocytosis in neurons and other cells are poorly understood. The purpose of this article is to consider some of the processes that control exocytosis, with special emphasis on the bovine adrenal chromaffin cell as a model system. Chromaffin cells are excitable cells and, like sympathetic nerves, are derived from the neural crest. Although chromaffin cells do not contain long processes or nerve terminals, secretion from chromaffin cells is stimulated by $\mathrm{Ca}^{2+}$ influx and inhibited by the clostridial neurotoxins (see below), which block exocytosis from the nerve terminals of peripheral and central nervous system neurons. Thus, it is likely that the secretory pathway in chromaffin cells is similar to that in neurons. Chromaffin cell secretory vesicles (chromaffin granules) are large, dense core vesicles that contain proteins, peptides, ATP, and the catecholamines epinephrine and norepinephrine. $\mathrm{Ca}^{2+}$ influx is stimulated in bovine chromaffin cells by activation of the nicotinic receptor/channel complex and voltagesensitive $\mathrm{Ca}^{2+}$ channels.
\end{abstract}

\section{EXOCYTOSIS AND GTP-BINDING PROTEINS}

Exocytosis is the last fusion event in the repeated sequence of vesicle budding and fusion that characterizes the passage of secretory proteins from the endoplasmic reticulum to the cell exterior (for review see ref. 1). Secretory vesicles leaving the trans golgi network are targeted to different locations. Some vesicles are targeted to lysosomes. Some go quickly to the plasma membrane where exocytosis occurs in a seemingly unregulated manner (constitutive secretion). ${ }^{2}$ Other vesicles fuse with the plasma membrane in a highly regulated manner. In the neuron, regulated exocytosis can occur meters away from the cell body where synthesis of the secretory vesicle membrane and intravesicular proteins occurs. Secretory vesicles involved in synaptic transmission journey to the nerve terminal by way of a microtubule-based transport system. After fusion with the plasma membrane, vesicle membrane recycles by way of endocytosis. In the case of small synaptic vesicles that store nonprotein neurotransmitters (e.g., acetylcholine), the recycled vesicles are reused locally for exocytosis. ${ }^{3}$

In endocrine cells and nerve terminals, the events leading to fusion of the

${ }^{a}$ This work was supported by NIH Grants RO1 DK27959 and PO1 HL18575. Part of the work presented was done when R. W. Holz was an Established Investigator of the American Heart Association. 
secretory vesicle with the plasma membrane are highly regulated. In most cases a rise in cytosolic $\mathrm{Ca}^{2+}$ from $0.1 \mu \mathrm{M}$ to micromolar or higher concentrations is the primary trigger for exocytosis. One of the major challenges in the study of the biochemistry of exocytosis is to distinguish those processes that are intimately involved in regulating exocytosis from the many processes activated by $\mathrm{Ca}^{2+}$. Although there are many possibilities (e.g., protein phosphorylation, cytoskeletal changes, changes in lipid metabolism: see below), at this time we do not know the critical events activated by $\mathrm{Ca}^{2+}$. An alternative approach is to consider whether regulated exocytosis in either endocrine cells or in nerve terminals has elements in common with the multiple fusion events occurring earlier in the biosynthetic pathway of secretory proteins.

The genetic analysis of protein secretion in yeast led to the identification and purification of SEC4p, which is necessary for fusion of post-Golgi vesicles with the plasma membrane, 4,5 and YPT1p, which is necessary for protein transfer from endoplasmic reticulum (ER) to Golgi. ${ }^{6}$ Both SEC4p and YPT1p are $23 \mathrm{kDa}$, GTP-binding proteins homologous to the ras family of GTP-binding proteins. They share $45 \%$ homology with each other. GTP-binding proteins are involved in the transfer and fusion of vesicles formed from donor cisternae (ER or Golgi compartments) to subsequent cisternae in the eukaryotic biosynthetic pathway. A nonhydrolyzable analogue of GTP $(\mathrm{GTP} \gamma \mathrm{S})$ prevents transfer of protein from ER to Golgi, and between Golgi compartments, ${ }^{8}$ and induces the accumulation of coated vesicles in the Golgi region ${ }^{9}$ and the accumulation of tubular-vesicular membranes near the ER. It has been postulated that GTP binding to vesicular protein and subsequent GTP hydrolysis are required for proper targeting and transfer of budding vesicles. ${ }^{10}$ An epitope in common with YPT1p is associated with mammalian Golgi. ${ }^{6}$

Do low molecular weight, GTP-binding proteins generally play an important role in targeting secretory vesicles or controlling fusion in regulated exocytosis? At this time the answer is unclear. Both chromaffin granules, the secretory vesicles in adrenal chromaffin cells, ${ }^{2,11}$ and bovine brain synaptic vesicles ${ }^{12,13}$ contain numerous GTP-binding proteins between 20 and $30 \mathrm{kDa}$. FIGURE 1A demonstrates the multitude of these proteins that are found on secretory vesicles. One can distinguish at least six proteins on bovine chromaffin granule membranes and on bovine brain synaptic vesicles. (These brain synaptic vesicles display active glutamate uptake. ${ }^{14,15}$ ) GTP-binding proteins from chromaffin granules and synaptic vesicles have identical mobilities in SDS-PAGE. A GTP-binding protein of approximately $45 \mathrm{kDa}$ can also be detected that probably corresponds to either $\alpha_{o}$ or $\alpha_{i}$, the pertussis toxin substrates for ADP-ribosylation that have been previously demonstrated on chromaffin granules. ${ }^{16}$ A quantitative analysis of GTP-binding sites on chromaffin granules (FIG. 1B) indicates that there are approximately $60 \mathrm{GTP}$-binding sites per chromaffin granule, which accounts for approximately $5 \%$ of the total granule membrane protein (see FIG. 1B legend). Nonhydrolyzable guanine nucleotides have a number of effects on secretion in permeabilized secretory cells. GTP $\gamma \mathrm{S}$ inhibits $\mathrm{Ca}^{2+}$-dependent secretion from electropermeabilized bovine chromaffin cells when added together with $\mathrm{Ca}^{2+17}$ and from digitonin-permeabilized bovine chromaffin cells when a low concentration of GTP $\gamma \mathrm{S}$ is incubated with permeabilized cells prior to stimulation with $\mathrm{Ca}^{2+}$ (FIG. 2 ). These effects are consistent with the effects of GTP $\gamma S$ to inhibit transfer and fusion of vesicles in earlier steps in the biosynthetic pathway of secretory proteins. The effects, however, depend upon cell type, method of plasma membrane permeabilization and experimental design. For example, nonhydrolyzable guanine nucleotides stimulate $\mathrm{Ca}^{2+}$-dependent secretion in electropermeabilized chicken chromaffin cells ${ }^{17}$ and in bovine chromaffin cells permeabilized by $\alpha$-toxin. ${ }^{18}$ Guanine nucleotides and $\mathrm{Ca}^{2+}$ are required for secretion from streptolysin-O-or digitoninpermeabilized mast cells in the presence of high concentrations of $\mathrm{Cl}^{-} .{ }^{19,20}$ When the 
$\mathrm{Cl}^{-}$concentration, however, is reduced ${ }^{19}$ or when protein kinase $\mathrm{C}$ is activated, ${ }^{20}$ either GTPyS or $\mathrm{Ca}^{2+}$ alone stimulates submaximal secretion. GTPyS also stimulates $\mathrm{Ca}^{2+}$-independent secretion from digitonin-permeabilized bovine chromaffin cells, ${ }^{21,22}$ and $\mathrm{PC} 12$ cells, ${ }^{23}$ and from mast cells using whole cell recording with the patch clamp. $^{2426}$ The multitude of effects of nonhydrolyzable guanine nucleotides on secretion is not surprising inasmuch as guanine nucleotides can activate a host of

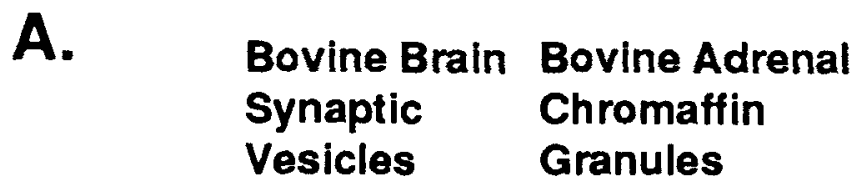

MW (kDa)
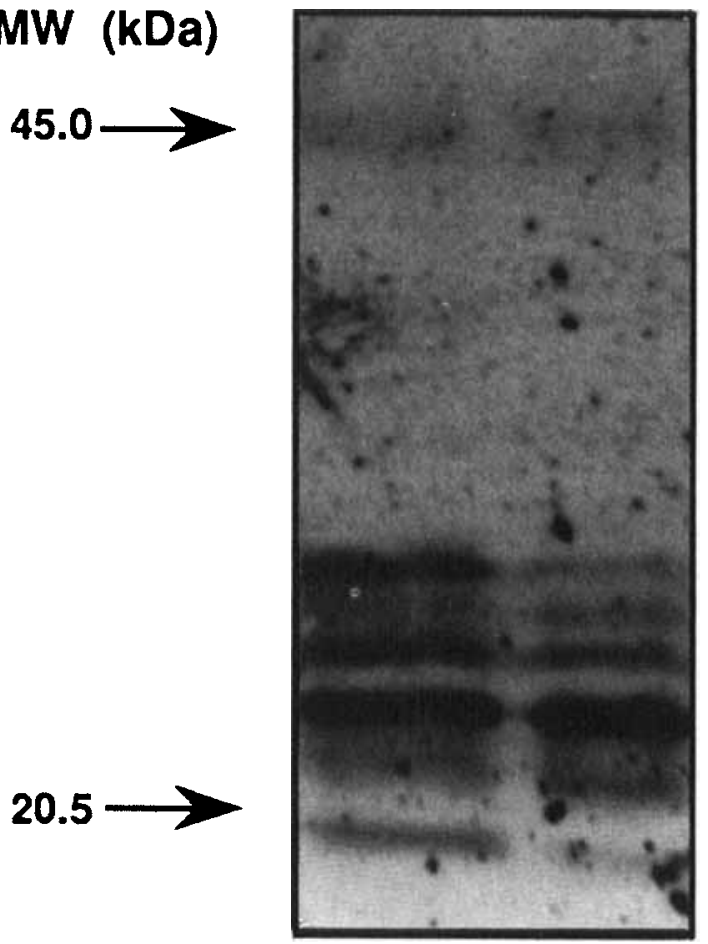

FIGURE 1A. GTP-binding proteins associated with bovine chromaffin granules and bovine brain glutamatergic synaptic vesicles. Chromaffin granules were purified from fresh bovine adrenal medulla. Adrenal glands were homogenized in $0.29 \mathrm{M}$ sucrose, $10 \mathrm{mM}$ Hepes ( $\mathrm{pH} 7.1$ ), $1 \mathrm{mM} \mathrm{Na} \mathrm{EDDTA}_{2} 1 \mathrm{mM}$ PMSF, and chromaffin granules purified using a discontinuous sucrose gradient according to Smith and Winkler, ${ }^{73}$ except that the large granule fraction was layered over a $1.7 \mathrm{M}$ sucrose solution. The gradient was centrifuged at $146,000 \times \mathrm{g}_{\text {ave }} \times 70 \mathrm{~min}$ in a Beckman 50.2 Ti rotor. The chromaffin granules were collected in the pellet, lysed in $10 \mathrm{mM}$ Hepes ( $\mathrm{pH} 7.1$ ), and washed twice and stored at -70 . Synaptic vesicles were purified from bovine brain according to the methods of Ueda and colleagues ${ }^{14.15}$ with an additional gel filtration step using Sephacryl 1000. The vesicle fraction concentrated glutamate in an ATPdependent manner. The molecular masses of the GTP-binding proteins are $20.1 \mathrm{kDa}, 22.4 \mathrm{kDa}$, $23.0 \mathrm{kDa}$ (dense band), $24.6 \mathrm{kDa}, 26.5 \mathrm{kDa}, 27.5 \mathrm{kDa}$, and $45 \mathrm{kDa}$. 
B.

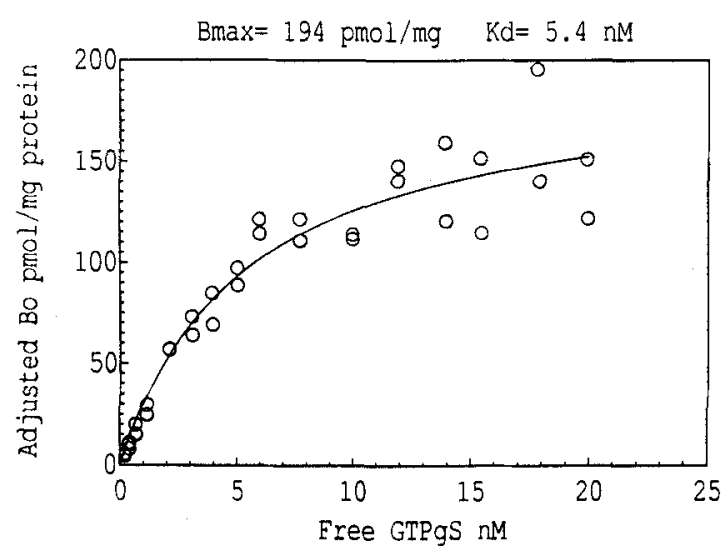

FIGURE 1B. Specific GTP $\gamma S$ binding to chromaffin granule membranes. Purified chromaffin granules $(2 \mu \mathrm{g} / \mathrm{mL})$ were incubated with various concentrations of nonradioactive GTP $\gamma \mathrm{S}$ and $0.235 \mathrm{nM}\left[{ }^{35} \mathrm{~S}\right] \mathrm{GTP} \gamma \mathrm{S}\left(0.23 \mu \mathrm{C}_{\mathrm{i}} / \mathrm{mL}\right)$ for $90 \mathrm{~min}$ at $30^{\circ} \mathrm{C}$. The suspension was passed through a nitrocellulose filter. The filter was washed extensively and the radioactivity determined. ${ }^{74}$ The data were analyzed by a nonlinear, least squares algorithm. Assuming a chromaffin granule diameter of 2800 angstroms, $17 \mu \mathrm{L}$ chromaffin granule volume $/ \mathrm{mg}$ membrane protein and maximal binding of 194 pmoles/mg membrane protein, one calculates 78 GTP $\gamma$ S binding sites/chromaffin granule. A similar experiment using a different preparation of granules yielded 130 pmoles GTP $\gamma \mathrm{S}$ binding/mg membrane protein and 52 GTP $\gamma \mathrm{S}$ binding sites/chromaffin granule. Approximately $4-6 \%$ of the total chromaffin granule membrane protein is GTPbinding protein, assuming an average molecular mass of $30 \mathrm{kDa}$ for GTP-binding proteins.

enzymes either directly or indirectly (e.g., adenylate cyclase, phospholipase C, phospholipase $A_{2}$, protein kinase $C$ ) that could influence the secretory response. Thus, it is unclear which, if any, of the effects of guanine nucleotides on secretion requires GTP-binding proteins on secretory vesicles. Furthermore, it is possible that the GTP-binding proteins associated with secretory vesicles are not directly involved in secretion but with other functions of the vesicles related to biosynthesis of the membrane ${ }^{27}$ or recycling after exocytosis.

\section{THE ROLE OF ATP IN SECRETION: PRIMING OF SECRETION, PROTEIN PHOSPHORYLATION, AND MAINTENANCE OF POLYPHOSPHOINOSITIDES}

Experiments with permeabilized chromaffin cells by Baker and Knight ${ }^{28,29}$ conclusively demonstrated a role for ATP hydrolysis in the intracellular pathway for exocytosis. Synaptic transmission occurs within less than a millisecond after invasion of the terminal by the action potential and the opening of voltage-sensitive $\mathrm{Ca}^{2+}$ channels. Because this is insufficient time for a cascade of biochemical reactions, ${ }^{30}$ the exocytotic machinary must be poised to respond rapidly to the rise in $\mathrm{Ca}^{2+}$. In experiments with the patch clamp in which incorporation of the granule membrane into the plasma membrane is measured by increases in plasma-membrane capacitance, depolarization-induced secretion from chromaffin cells occurs within the time 


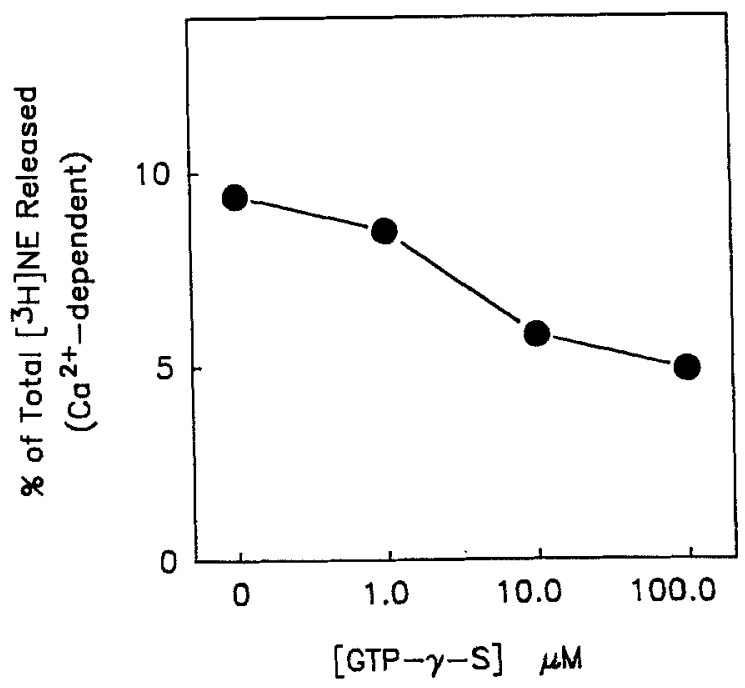

FIGURE 2. GTP $\gamma S$ inhibits secretion from digitonin-permeabilized chromaffin cells. $\left[{ }^{3} \mathrm{H}\right]$ norepinephrine-labeled chromaffin cells were permeabilized by incubation in KGEP [139 $\mathrm{mM}$ potassium glutamate, $5 \mathrm{mM}$ EGTA, $20 \mathrm{mM}$ PIPES ( $\mathrm{pH}$ 6.6), $1 \mathrm{mM} \mathrm{MgCl}$, and $5 \mathrm{mg} / \mathrm{mL} \mathrm{BSA}$ ] containing $2 \mathrm{mM}$ MgATP, $20 \mu \mathrm{M}$ digitonin, and various concentrations of GTP $\gamma \mathrm{S}$. After $4 \mathrm{~min}$, the solution was replaced with digitonin-free KGEP without MgATP and GTP $\gamma$ S, and with and without $10 \mu \mathrm{M}$ free $\mathrm{Ca}^{2+} . \mathrm{Ca}^{2+}$-dependent secretion was determined after $2 \mathrm{~min}$. Secretion in the absence of $\mathrm{Ca}^{2+}$ was $1.6-2.4 \%$. GTP $\gamma \mathrm{S}$ at all concentrations released less than $1 \%$ of the catecholamine during the incubation with digitonin. There were 3 wells/group.

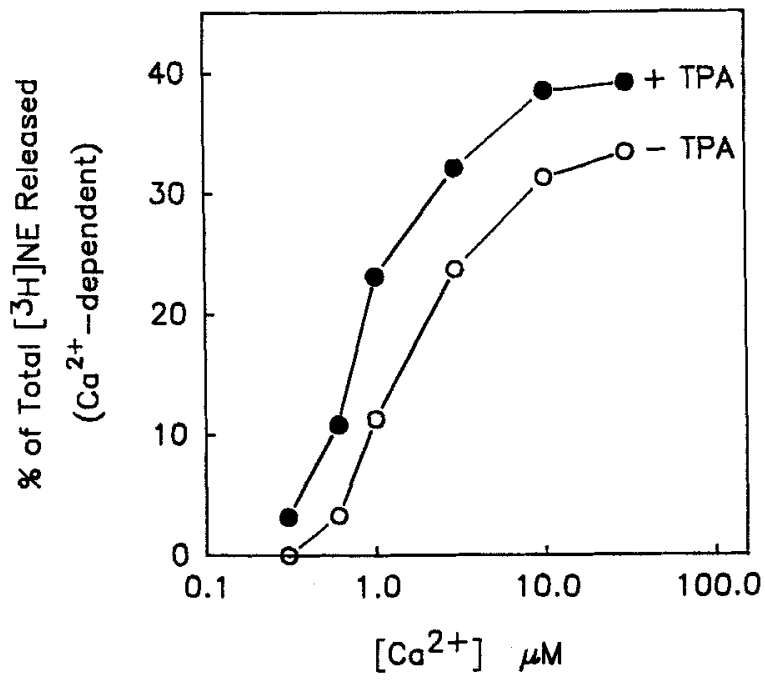

FIGURE 3. The phorbol ester TPA enhances secretion from digitonin-permeabilized chromaffin cells. $\left.{ }^{3} \mathrm{H}\right]$ norepinephrine-labeled cells were incubated for 30 $\min$ in MEM with or without $20 \mathrm{nM}$ TPA. The cells were permeabilized in KGEP containing $2 \mathrm{mM}$ MgATP with indicated $\left[\mathrm{Ca}^{2+}\right] . \mathrm{Ca}^{2+}$-dependent secretion was determined after $15 \mathrm{~min}$. Secretion in the absence of $\mathrm{Ca}^{2+}$ was 3.4 $3.6 \%$. There were 3 wells/ group. 
FIGURE 4. The protein kinase $C$ inhibitor peptide $\mathrm{PKC}(19-31)$ inhibits $\mathrm{Ca}^{2+}$-dependent secretion in TPA-treated but not in TPA-untreated chromaffin cells. $\left[{ }^{3} \mathrm{H}\right]$ norepinephrine-labeled cells were incubated for $15 \mathrm{~min}$ with (filled circles) or without (unfilled circles) $60 \mathrm{nM}$ TPA in physiolog. ical salt solution. Cells were permeabilized for 6 min in $\mathrm{Ca}^{2+}$-free potassium glutamate solution (KGEP) containing $20 \mu \mathrm{M}$ digitonin in the presence or absence of increasing concentrations of PKC(19-31). The solution was replaced with KGEP with or without $1 \mu \mathrm{M} \mathrm{Ca}^{2+}$ in the continuing presence or absence of $\mathrm{PKC}(19-31) . \mathrm{Ca}^{2+}$ dependent secretion was measured after $5 \mathrm{~min}$. Release in the absence of $\mathrm{Ca}^{2+}$ was $3.1-4.4 \%$. There were 3 wells/group. ${ }^{42}$

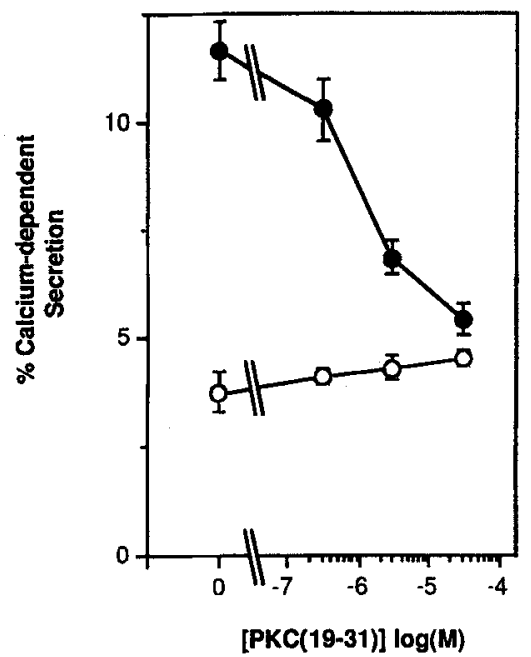

resolution of the experiments (several hundred milliseconds).$^{31}$ In experiments in which release of catecholamine is detected biochemically, the maximal rate of secretion occurs within the first 1-2 min and then slows ${ }^{32}$; secretion can be reproducibly detected within 10 seconds. ${ }^{33}$ We found that the rapid initial rate of catecholamine secretion requires prior incubation with ATP. ${ }^{32}$ Although the time scale of the experiments is orders of magnitude slower than the events following $\mathrm{Ca}^{2+}$ entry in the nerve terminal, the experiments nevertheless demonstrate that ATP acts before $\mathrm{Ca}^{2+}$ to prime the cell to respond to $\mathrm{Ca}^{2+}$. A similar conclusion can be drawn from experiments with mast cells. ${ }^{34}$

ATP is required for protein phosphorylation, and there is abundant evidence that protein phosphorylation modulates exocytosis. In the squid giant synapse ${ }^{35}$ and mammalian synaptosomes ${ }^{36} \mathrm{Ca} /$ calmodulin kinase II enhances secretion, perhaps by

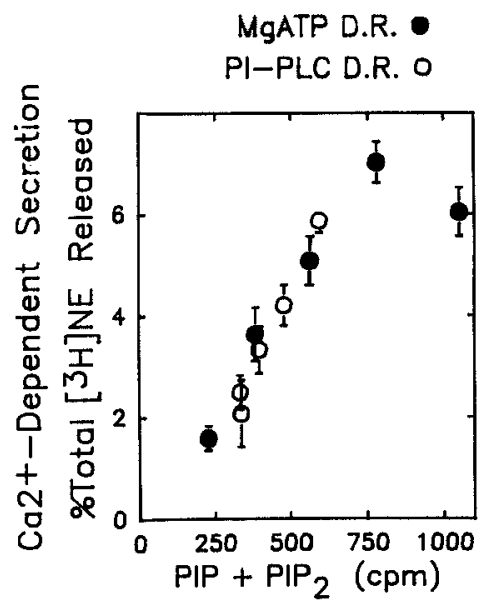

FIGURE 5. The relationship between the levels of the polyphosphoinositides and $\mathrm{Ca}^{2+}$-dependent secretion in digitonin-permeabilized chromaffin cells. The polyphosphoinositides were varied in digitoninpermeabilized cells by varying the concentrations of MgATP or by varying the concentrations of a PtdInsspecific phospholipase $\mathrm{C}$ from Bacillus thuringiensis. $\left.{ }^{3} \mathrm{H}\right]$ Inositol-labeled cells were permeabilized for 8 min in $\mathrm{Ca}^{2+}$-free potassium glutamate solution (KGEP) containing either various amounts of MgATP or $2 \mathrm{mM} \mathrm{MgATP}$ and various amounts of bacterial phospholipase $C$. The levels of $\left[{ }^{3} \mathrm{H}\right]$ inositollabeled PtdIns, PtdInsP, and PtdIns $\mathrm{P}_{2}$ were determined after an additional $3 \mathrm{~min}$ incubation in $10 \mu \mathrm{M}$ $\mathrm{Ca}^{2+}$ in the continuing presence of MgATP. Bacterial phospholpase $C$ was not present in the last incubation. $\mathrm{Ca}^{2+}$-dependent secretion from $\left[{ }^{3} \mathrm{H}\right]$ norepinephrine-labeled cells was determined in parallel experiments at 6 min. For details see FIG. 5 in ref. 45. 

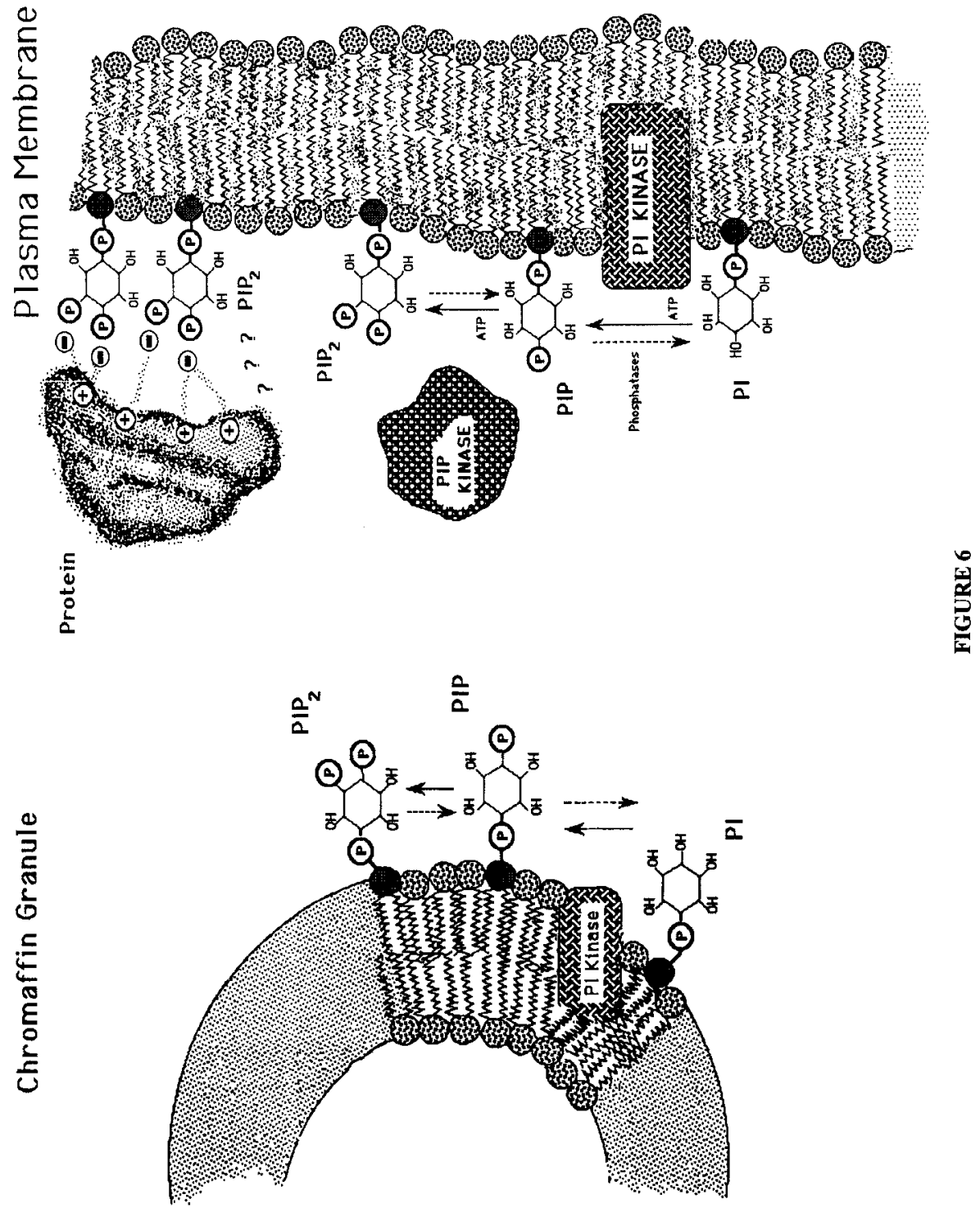
phosphorylation of synapsin I. In many secretory cells including chromaffin cells, activation of protein kinase $\mathrm{C}$ increases the ability of cells to respond to submicromolar and micromolar $\mathrm{Ca}^{2+} \cdot{ }^{37-39}$ FIGURE 3 demonstrates effects of the protein kinase $\mathrm{C}$ activator TPA (12-O-tetradecanoylphorbol acetate) on the $\mathrm{Ca}^{2+}$ dose-response relation for secretion from permeabilized cells. Because cellular protein kinase C can be activated by $\mathrm{Ca}^{2+}$ in the absence of exogenous activators, ${ }^{33,40}$ an important issue is whether protein kinase $\mathrm{C}$ is required for secretion and is responsible for the ATP dependency. We have recently addressed this issue in permeabilized chromaffin cells using a specific inhibitor of protein kinase C. The synthetic peptide PKC(19-31), which is derived from the pseudosubstrate sequence of protein kinase $C$, is a potent inhibitor of protein kinase $\mathrm{C}$ in vitro ${ }^{41}$ and in situ within permeabilized cells. ${ }^{42}$ Although it inhibited phorbol ester-induced secretion in the presence of $\mathrm{Ca}^{2+}$ almost completely, it had no effect on $\mathrm{Ca}^{2+}$-dependent secretion in the absence of phorbol ester (FIG. 4). Thus, it is unlikely that the ATP-dependency for secretion reflects the necessary involvement of protein kinase $C$ in the secretory pathway. Similarly, it is unlikely that calmodulin-dependent protein kinase or other calmodulin-dependent processes play a necessary role in secretion from permeabilized cells. Relatively high concentrations of the calmodulin antagonists trifluoperazine and calmidazolium have either partial effects in electropermeabilized chromaffin cells ${ }^{29,43}$ or virtually no effects in digitonin-permeabilized chromaffin cells (Holz, unpublished observations). Furthermore, an anticalmodulin antibody (Holz, unpublished observations) and a calmodulin-binding peptide ${ }^{42}$ have no effect on secretion from digitonin-permeabilized chromaffin cells. The ability of an anticalmodulin antibody to inhibit secretion when injected into intact cells ${ }^{44}$ may reflect a role for calmodulin in the events leading to a rise in cytosolic $\mathrm{Ca}^{2+}$.

These data led us to consider other reactions in which ATP may be involved. We found that the maintenance of the polyphosphoinositides by PI and PIP kinases occurred over the same MgATP concentration range as that necessary to maintain exocytosis. ${ }^{45}$ We also found that in the presence of MgATP we could manipulate the levels of the polyphosphoinositides by a bacterial phospholipase $\mathrm{C}$ that hydrolyzed their precursor, phosphatidylinositol. The polyphosphoinositides declined because of the action of endogenous lipid phosphatases in the absence of continued synthesis. The relationship between $\mathrm{Ca}^{2+}$-dependent secretion and the polyphosphoinositides was the same whether the lipids were manipulated by varying the MgATP concentration or by varying the concentration of the bacterial phospholipase $C$ (FIGURES 5 and 6). The inhibitory effects of the exogenous phospholipase $C$ could not be explained by the products of the bacterial phospholipase $\mathrm{C}$ reaction ( $\mathrm{IP}_{1}$ and diacylglycerol) or the loss of products from the endogenous phospholipase $C$ (due to the loss of the polyphosphoinositide substrates). The simplest and most compelling interpretation is that the polyphosphoinositides are necessary in the secretory pathway. Thus, ATP

FIGURE 6. Polyphosphoinositide metabolism in chromaffin cells. The polyphosphoinositides are synthesized from phosphatidylinositol by PI and PIP kinases. In resting cells, PIP phosphatase and PIP phosphatase are responsible for degrading the polyphosphoinositides. Phospholipase $\mathrm{C}$ activated by receptor-mediated mechanisms or by a rise in cytosolic $\mathrm{Ca}^{2+75}$ breaks down PIP $_{2}$ to $\mathrm{IP}_{3}$ and diacylglycerol (not shown). Experiments in which the polyphosphoinositides are decreased by ATP or by hydrolysis of PI with a bacterial phospholipase C demonstrate a close correlation between the levels of the polyphosphoinositides and $\mathrm{Ca}^{2+}$ dependent secretion. ${ }^{45}$ Thus, reducing either substrate for PI kinase reduces the polyphosphoinositides and $\mathrm{Ca}^{2+}$-dependent secretion. The requirement for the polyphosphoinositides in secretion could reflect the importance of a protein that binds to and is regulated by these lipids. 
is important not only for modulation of secretion by protein kinases, but also for maintenance of the polyphosphoinositides.

Polyphosphoinositides are synthesized both on the plasma membrane ${ }^{47}$ and on the chromaffin granule membrane ${ }^{48-50}$ (FIG. 6). The binding of a protein to $\mathrm{PIP}_{2}$ (and/or PIP) on either membrane may regulate its function in secretion. There are at least two proteins, myosin I and gelsolin, that bind to the polyphosphoinositides and to actin. Myosin I, which causes actin-dependent organelle movement, has recently been demonstrated to bind to $\mathrm{PIP}_{2}{ }^{51}$ The ability of gelsolin to cause $\mathrm{Ca}^{2+}$-dependent severing of f-actin is inhibited by polyphosphoinositides ${ }^{52}$ (for review see ${ }^{53}$ ). Because chromaffin granules also interact with $\mathrm{f}$-actin, ${ }^{54-56}$ it is possible that the PIP ${ }_{2}$ or PIP localizes these proteins to secretory sites and controls the interaction of chromaffin granules with the cortical cytoskeleton and the plasma membrane. In addition, calpactin I, which interacts with acidic phospholipids including the polyphosphoinositides, ${ }^{57}$ aggregates and under some conditions allows fusion of chromaffin granules in vitro. ${ }^{58,59}$ Indeed, recent reports suggest that calpactin is in intimate contact with chromaffin granules, and the plasma membrane in intact cells, ${ }^{60}$ and can maintain secretion in digitonin-permeabilized chromaffin cells. ${ }^{61,62}$

\section{CLOSTRIDIAL NEUROTOXINS DIRECTLY INHIBIT THE EXOCYTOTIC PATHWAY}

Botulinum and tetanus neurotoxins (clostridial neurotoxins) block neurotransmitter release from various neurons and are thought to interact with critical sites in the exocytotic pathway. ${ }^{63}$ Botulinum type $D$ neurotoxin interacts with bovine tissues and inhibits secretion from both intact and electropermeabilized bovine chromaffin cells. ${ }^{64}$ Extracellular application of botulinum types A, B, or E neurotoxin or tetanus neurotoxin has no effect on intact bovine chromaffin cells because of the absence of receptors on the plasma membrane. The introduction of these toxins, however, into cells through a patch-clamp electrode ${ }^{65}$ or by incubation with digitonin-or streptolysin O (SL-O)-permeabilized cells ${ }^{66-69}$ inhibits secretion. Experiments with permeabilized cells demonstrate that the light chain $(50 \mathrm{kDa})$ of the dichain molecules $(150$ $\mathrm{kDa}$ ) is responsible for the inhibition of secretion. ${ }^{67,68,70}$ The ability of these classical inhibitors of synaptic transmission to inhibit exocytosis from chromaffin cells indicates that there are common elements in the secretory pathway in neurons and chromaffin cells. The toxins decrease the maximal extent of secretion and not the sensitivity to $\mathrm{Ca}^{2+}{ }^{66,67}$ Interestingly, the toxins do not all act alike. Both tetanus toxin and botulinum $B$ neurotoxins completely inhibit secretion, whereas botulinum $A$ neurotoxin, even at high concentrations, inhibits secretion by no more than 70 percent. Thus, the toxins may interact with different sites in the secretory pathway. At the intact neuromuscular junction, the effects of tetanus and botulinum $B$ neurotoxins can also be distinguished from those of botulinum $A$ neurotoxin. Tetanus and botulinum $B$ neurotoxins reduce evoked miniature end-plate potentials (MEPPS) and desynchronize those MEPPS that are observed. ${ }^{7}$ Botulinum A neurotoxin also reduces evoked MEPPS but without desynchronizing the residual MEPPS. Key issues for future investigation are the sites of interaction of the light chains of these toxins within nerve terminals and chromaffin cells and the possibility that they may act through an unknown enzymatic activity. The ADP-ribosylating activity of neurotoxin preparations is likely to be caused by contaminating ADPribosyl transferase activity (C-3 toxin). ${ }^{72}$ 


\section{ACKNOWLEDGMENTS}

We are grateful to Dr. T. Ueda and Dr. J. Tabb (Mental Health Research Institute and the Department of Pharmacology, University of Michigan) for providing us with purified bovine brain synaptic vesicles. We thank Peter Wick (Department of Pharmacology, University of Michigan Medical School) for preparing FIGURE 6.

\section{REFERENCES}

1. BALCH, W. E. 1989. J. Biol. Chem. 264: 16965-16968.

2. Burgess, T. L. \& R. B. Kelly. 1987. Annu. Rev. Cell Biol, 3: 243-294.

3. Torri-Tarelli, F., A. Villa, F. Valtorta, P. De Camilli, P. Greengard \& B. CeCCARELli. 1990. J. Cell Biol. 459: 449-459.

4. Novick, P., C. Field \& R. SCHEKMAN. 1980. Cell 21: 205-215.

5. Goud, B., A. Salminen, N. C. Walworth \& P. J. Novick. 1988. Cell 53: 753-768.

6. Segev, N., J. Mulholland \& D. Botstein. 1988. Cell 52: 915-924.

7. BeCKERS, C. J. \& W. E. BALCH. 1989. J. Cell Biol. 108: 1245-1256.

8. Melancon, P., B. S. Glick, V. Malmotra, P. J. Weidman, T. Serafini, M. L. Gleason, L. ORCI \& J. E. ROTHMAN. 1987. Cell 51: 1053-1062.

9. Rothman, J. E. \& L. OrCi. 1990. FASEB J. 4: 1460-1468.

10. BOURNE, H. R. 1988. Cell 53: 669-671.

11. Burgoyne, R. D. \& A. MORGAN. 1989. FEBS Lett. 245: 122-126.

12. Bielinski, D. F., P. J. Morin, B. F. Dickery \& R. E. Fine. 1989. J. Biol. Chem. 264: $18363-18367$.

13. Mollard, G. F. v., G. A. Mignery, M. Baumert, M. S. Perin, R. J. Hanson, P. M. BURger, R. JAHN \& T. C. SUdHOF. 1990. Proc. Natl. Acad. Sci. USA 87: 1988-1992.

14. KISH, P. E. \& T. UeDA. 1986. Glutamate accumulation into synaptic vesicles. In Methods in Enzymology Biomembranes Part V. S. Fleischer \& B. Fleischer, Eds.: 174: 9-25. Academic Press. New York.

15. Carlson, M. D., P. E. Kish \& T. Ueda. 1989. J. Biol. Chem. 264: 7369-7376.

16. Toutant, M., D. Aunis, J. Bockaert, V. Homburger \& B. Rouot. 1987. FeBS Lett. 215: 339-344.

17. KNIGHT, D. E. \& P. F. BAKER. 1985. FEBS Lett. 189: 345-349.

18. Bader, M.-F., J.-M. Sontag, D. Thierse \& D. Aunis. 1989. J. Biol. Chem. 264: 1642616434.

19. Churcher, Y. \& B. D. Gomperts. 1990. Cell Regul. 1: 337-346.

20. KOOPMAN, W. R. \& R. C. JACKSON. 1990. Biochem. J. 265: 365-373.

21. Bittner, M. A., R. W. Holz \& R. R. Neubig. 1986. J. Biol. Chem. 261: 10182-10188.

22. Morgan, A. \& R. D. BuRgoyne. 1990. Biochem. J. 269: 521-526.

23. Carroll, A. G., A. R. Rhoads \& P. D. Wagner. 1990. J. Neurochem. 55: 930-936.

24. FernandeZ, J. M., E. NEHER \& B. D. GOMPERTS. 1984. Nature 312: 453-455.

25. Zimmerberg, J., M. Curran, F. S. Cohen \& M. Brodwick. 1987. Proc. Natl. Acad. Sci. USA 84: $1585-1589$.

26. BreckenRIdge, L. J. \& W. Almers. 1987. Proc. Natl. Acad. Sci. USA 84: 1945-1949.

27. TOOZE, S. A., U. Weiss \& W. B. HutTNER. 1990. Nature 347: 207-208.

28. BAKER, P. F. \& D. E. KNIGHT. 1978. Nature 276: 620-622.

29. KNIGHT, D. E. \& P. F. BAKER. 1982. J. Membr. Biol. 68: 107-140.

30. Almers, W. 1990. Annu. Rev. Physiol. 52: 607-624.

31. Neher, E. \& A. MARTY. 1982. Proc. Natl. Acad. Sci. USA 79: 6712-6716.

32. Holz, R. W., M. A. Bittner, S. C. Peppers, R. A. Senter \& D. A. Eberhard. 1989. J. Biol. Chem. 264: 5412-5419.

33. TerBush, D. R., M. A. Bittner \& R. W. Holz. 1988. J. Biol. Chem. 263: 18873-18879.

34. Howell, T. W., I. M. Kramer \& B. D. Gomperts. 1989. Cellular Signal. 1: 157-163.

35. Llinás, R., R. L. McGuinness, C. S. Leonard, M. Sugimori \& P. Greengard. 1985. Proc. Natl. Acad. Sci. USA 82: 3035-3039. 
36. Nichols, R. A., T. S. Sihra, A. J. Czernik, A. C. Nairn \& P. Greengard. 1990. Nature 343: 647-651.

37. KNIGHT, D. E. \& P. F. BAKER. 1983. FEBS Lett. 160: 98-100.

38. Pocotte, S. L., R. A. Frye, R. A. Senter, D. R. Terbush, S. A. Lee \& R. W. Holz. 1985. Proc. Natl. Acad. Sci. USA 82: 930-934.

39. Brocklehurst, K. W., K. Morita \& H. B. Pollard. 1985. Biochem. J. 228: 35-42.

40. TERBush, D. R. \& R. W. Holz. 1986. J. Biol. Chem. 261: 17099-17106.

41. HOUSE, C. \& B. E. KEMP. 1987. Science 238: 1726-1728.

42. TerBush, D. R. \& R. W. Holz. 1990. J. Biol. Chem. 265: 21179-21184.

43. KNight, D. E., D. Sugden \& P. F. BAKER. 1988. J. Membr. Biol. 104: 21-34.

44. Kenigsberg, R. L. \& J. M. Trifaro. 1985. Neurosci. 14: 335-347.

45. Eberhard, D. A., C. L. Cooper, M. G. Low \& R. W. Holz. 1990. Biochem. J. 268: 15-25.

46. Edelman, A. M., D. K. Blumenthal \& E. G. Krebs. 1987. Annu. Rev. Biochem. 56: $567-613$.

47. Berridge, M. J. 1987. Annu. Rev. Biochem. 56: 159-193.

48. Buckley, J. T., Y. A. Lefebvre \& J. N. Hawthorne. 1971. Biochim. Biophys. Acta 239: 517-519.

49. Muller, T. W. \& N. KiRSHNER. 1975. J. Neurochem. 24: 1155-1161.

50. PHILliPS, J. H. 1973. Biochem. J. 136: 579-587.

51. ADAMS, R. J. \& T. D. POlLARD. 1989. Nature 340: 565-568.

52. Janmey, P. A. \& T. P. STOSSEl. 1989. J. Biol. Chem. 264: 4825-4831.

53. YIN, H. L. 1987. Bioessays 7: 176-179.

54. BurRidge, K. \& J. A. Phillips. 1975. Nature 254: 526-529.

55. WiLkins, J. A. \& S. LiN. 1981. Biochim. Biophys. Acta 642: 55-66.

56. Fowler, V. M. \& H. B. Pollard. 1982. Nature 295: 336-339.

57. GLENNEX, J. 1986. J. Biol. Chem. 261: 7247-7252.

58. Drust, D. S. \& C. E. Creutz. 1988. Nature 331: 88-91.

59. GLeNNEY, J. R. 1987. Bioessays 7: 173-175.

60. Nakata, T., K. Sobue \& N. Hirokawa. 1990. J. Cell Biol. 110: 13-25.

61. ALI, S. M., M. J. Geisow \& R. D. BuRGoYNE. 1989. Nature 340: 313-315.

62. Ali, S. M. \& R. D. BurgoYNE. 1990. Cellular Signal. 2: 265-276.

63. SimPSON, L. L. 1986. Annu. Rev. Pharmacol. Toxicol. 26: 427-453.

64. KNIGHT, D. E., D. A. Tonge \& P. F. BAKER. 1985. Nature 317: 719-721.

65. PenNer, R., E. NeHER \& F. DReYer. 1986. Nature 324: 76-78.

66. BitTNeR, M. A. \& R. W. Holz. 1988. J. Neurochem. 51: 451-456.

67. Bittner, M. A., B. R. DasGupta \& R. W. Holz. 1989. J. Biol. Chem. 264: 10354-10360.

68. Ahnert-Hilger, G., U. Weller, M. E. Dauzenroth, E. Habermann \& M. Gratzl. 1989. FEBS Lett. 242: 245-248.

69. Stecher, B., M. Gratzl \& G. AhnerT-Hilger. 1989. FEBS Lett. 248: 23-27.

70. BitTner, M. A., W. H. Habig \& R. W. Holz. 1989. J. Neurochem. 53: 966-968.

71. Gansel, M., R. Penner \& F. Dreyer. 1987. Pfluegers Arch. 409: 533-539.

72. Adam-Vizi, V., S. Rosener, K. AKtories \& D. E. Knight. 1988. FEBS Lett. 238: 277280.

73. SMITH, A. D. \& H. WinkLER. 1967. Biochem. J. 103: 480-482.

74. Sternweis, P. C. \& J. D. Robishaw. 1984. J. Biol. Chem. 259: 13806-13813.

75. Eberhard, D. A. \& R. W. Hol.z. 1987. J. Neurochem. 49: 1634-1643. 